УДК 378.14 + 37.013.73

\author{
Оксана Казакова, \\ ORCID iD 0000-0002-8609-8699 \\ заступник директора з наукової роботи \\ Миколаӥвський муніичипальний колегіум ім. В. Д. Чайки \\ вул. Котельна, 8, 54000, м. Миколаїв, Україна \\ oksiniki@ukr.net
}

Ганна Пономаренко, ORCID iD 0000-0002-0538-3616 методист кафедри теорії й методики мовно-літературної та художньо-естетичної освіти Миколаївський обласний інститут післядипломної педагогічної освіти вул. Адміральська, 4-а, 54001, м. Миколаїв, Украӥна anna.ponomarenko@moippo.mk.ua

\section{РОЗВИТОК МЕДІАКОМПЕТЕНТНОСТІ ВЧИТЕЛЯ ЛІТЕРАТУРИ В КОНТЕКСТІ ДІЯЛЬНОСТІ ІНСТИТУТІВ ПІСЛЯДИПЛОМНОЇ ПЕДАГОГІЧНОЇ ОСВІТИ}

Статтю присвячено одному з актуальних питань сучасної вітчизняної педагогічної науки - медіакомпетентності вчителя. Зокрема розкривається сутність таких понять, як медіаосвіта, медіаграмотність, медіаобізнаність, медіакомпетентність. Увага зосереджується на з'ясуванні ступеня розроблення досліджуваної проблеми в науковому та нормативно-правовому полі України: розглянуто Концепцію «Нова українська школа», Конщепцію впровадження медіаосвіти в Україні.

Визначено підходи до впровадження медіаосвіти в Украйнський освітній простір, ї̈ мету, завдання. Зазначено основні функиії педагога, щчо необхідні для формування медіакомпетентності учнів. Указано суперечності, щз заважають ефективно реалізовувати програму Нової украӥнської школи щуодо імплементації медіаосвіти в шкільний простір (на киталт розбіжностей між сучасними вимогами суспільства до професійної діяльності вчителя, яка має забезпечити створення медіаосвітнього середовища, та здебільшого неготовністю педагогів до ї̈ здійснення).

У статті порушуються питання медіаінформаційної грамотності, медіаімунітеmу особистості, рефлексї та критичного мислення (як психологічних механізмів, щзо забезпечують свідоме споживання медіапродукиії $i$ саморегуляиію взаємодії з медіа), здатності до медіатворчості та спеціалізованих аспектів медіакультури.

Ключові слова: кібербулінг; медіаграмотність; медіазалежність; медіакомпетентність; медіакомпетенція; медіакультура; медіаобізнаність; медіаосвіта.

(C) Казакова О. М., Пономаренко Г. В., 2021

Вступ. У законі України «Про освіту», розробленому на основі Концепції «Нова українська школа», проголошено курс на впровадження компетентнісного підходу в освіті. Медіаграмотність визнано однією 3 ключових компетентностей XXI століття значною кількістю організацій: від $\mathrm{OOH}$ до професійних освітніх інституцій. Нині в Україні розробляють нові освітні стандарти, у яких медіаграмотність визначено як наскрізну компетентність. Концепцією «Нова українська школа» передбачено, що формування медіаграмотності має відбуватись у двох основних напрямах: перВересень № 1 (88) 2021 
ший - медіаосвіта як складова інформаційно-цифрової компетентності, другий - це інтеграція елементів інформаційної та медійної грамотності в зміст усіх освітніх галузей. Також потрібно додати, що у зв'язку з уведенням у дію Указу Президента України № 47/2017 від 25 лютого 2017 року, Доктрини інформаційної безпеки України питання розвитку медіакультури суспільства віднесено до національних інтересів держави, а підвищення рівня медіаграмотності особистості визначено як один із пріоритетів державної політики. На сьогоднішній день в Україні активно реалізується Концепція впровадження медіаосвіти (нова редакція) (схвалено постановою Президії Національної академії педагогічних наук України від 21 квітня 2016 року). У документі йдеться про те, що в сучасному світі, коли знання швидко змінюються, а зміст освіти відповідає потребам повсякденного життя людини, медіаосвіта має стати одним із головних чинників забезпечення відкритості освіти (Концепція впровадження медіаосвіти в Україні).

Поділяємо думку вітчизняної вченої Л. А. Назаренко, яка зазначає, що «медіакомпетентність $\epsilon$ основною складовою навчального процесу, вимагає вольових зусиль у подоланні труднощів та реалізується за допомогою цілепокладання, поетапного виконання розумових дій та креативного використання сукупності мотивів, знань, умінь, здатностей, ставлень до інформації» (Nazarenko L., Palamar S., 2020, c. 273). Це твердження стосується як учнів, так і вчителів, адже, на думку українського дослідника А. О. Срмоленко, «завдання сучасного педагога: розвивати критичне мислення дитини, вміння аналізувати й відбирати важливу інформацію, структурувати, узагальнювати, використовувати й осмислено створювати для інформаційного середовища власні медіатексти, формувати медіакультуру школярів» (Срмоленко А. О., 2016, c. 330-333).

Зазначене вище зумовлює визначення нових функцій педагога в медіаосвіті школярів, які пов’язані з:
- формуванням у педагогів системи знань про особливості інформаційного суспільства, про виклики i ризики, що спричинені його впливом на школярів різних вікових категорій, про основи рефлексивного підходу до освіти в інформаційному суспільстві, про пріоритетні принципи рефлексивного управління віртуальним простором;

- оволодінням найсучаснішими технологіями медіа, які допоможуть ефективно викладати шкільні дисципліни, запобігти віртуалізації повсякденного життя учнів, їхньому інформаційному перевантаженню та які будуть протистояти потенційно небезпечним феноменам поствіртуальної реальності.

Із виникненням нових функцій педагога щодо медіаосвіти школярів виникає необхідність їх дослідження та окреслення шляхів вирішення зазначеної проблеми. Визнання педагогічною наукою та практикою необхідності впровадження в систему післядипломної педагогічної освіти сучасних форм і методів навчання, що розвивають у вчителів медіакомпетентність, та долання наявних суперечностей між: вимогами сучасного суспільства до професійної діяльності вчителя, яка забезпечуватиме створення медіаосвітнього середовища, та здебільшого неможливістю педагогів здійснювати таку діяльність; потребою в новітніх медіаосвітніх технологіях для учнів із різними пізнавальними інтересами та різних вікових категорій і браком науково-методичного забезпечення застосування сучасних медіатехнологій в освітньому процесі, доводять актуальність і доцільність дослідження. Ще одна суттєва проблема медіаосвіти, на думку В. Ф. Іванова та Т. В. Іванової, полягає в тому, що «чим більше інформації, тим менше знань. Є лише велика кількість слабко пов'язаних між собою фактів. Відсутня система, втрачається причинно-наслідковий зв'язок» (Іванов В. Ф., 2014, с. 96-99). Саме вчитель має навчити учнів фільтрувати, аналізувати 
та систематизувати отриману інформацію.

Мета статті полягає у висвітленні реалізації вітчизняної Концепції впровадження медіаосвіти в умовах інститутів післядипломної педагогічної освіти через створення творчих груп (на прикладі роботи обласної творчої групи вчителів зарубіжної літератури закладів загальної середньої освіти Миколаївської області «Розвиток медіакомпетентності вчителя літератури»). Реалізація мети потребує висвітлення таких завдань: з'ясувати ступінь розроблення досліджуваної проблеми в нормативно-правовому полі та в спеціальній педагогічній та психологічній літературі; висвітлити основні суперечності між вимогами сьогодення та підготовкою педагогів, окреслити основні функції вчителя, що необхідні для формування медіакомпетентності учнів; описати програму, форми та результати роботи обласної творчої групи «Розвиток медіакомпетентності вчителя літератури».

Медіакомпетентність педагога в науковому дискурсі. Нормативно-правовий аспект. Усеукраїнські експерименти.

Проблема розвитку в учителів компетентностей стала предметом дослідження під час вирішення низки теоретичних і прикладних питань, що пов'язані з: особливостями науково-педагогічного супроводу професійного зростання педагогів (В. В. Дивак, Ю. М. Казаков, Л. А. Найдьонова, Н. Г. Протасова, Л. П. Сущенко); розробленням концепції неперервної освіти вчителів та підвищення їхньої кваліфікації (М. Т. Громкова, О. А. Дубасенюк, С. І. Змєєв, Н. Г. Ничкало); вивченням готовності педагога до різних видів педагогічної діяльності (А. Й. Капська, О. М. Пєхота); виокремленням психологічних засад підготовки та перепідготовки педагогічних працівників (О. Ю. Клепцова, М. М. Рубінштейн); пошуком сучасних підходів до розвитку інноваційної культури вчителів зокрема та підвищення кваліфікації педагогів у цілому (П. Ф. Анісімов, Н. Ю. Конасова); характеристикою основних психолого-педагогічних засад фор- мування й розвитку професійної компетентності педагогів-практиків (О. I. Гура, I. О. Зимня, Н. В. Кузьмина, В. О. Сластьонін та ін.); з'ясуванням особливостей упровадження новітніх інформаційно-комунікаційних технологій в освітньому процесі (Р. С. Гуревич, А. І. Кучай, та ін.); формуванням медіаграмотності педагогів та учнів (О. Т. Боришполець, О. В. Волошенюк, Кен Рігбі, О. Д. Маланцева, Л. А. Найдьонова, В. Р. Петросянц, Р. Дж. Хазлер). Проблеми, виокремлені вченими, потребують пошуку ефективних підходів до розвитку медіакомпетентності вчителя, під якою ми розуміємо «здатність розуміти, аналізувати й оцінювати зміст медіа, уміння використовувати медіа під час навчання і дозвілля, бути співтворцем особистого змісту в мас-медіа, володіти навичками самопрезентації та спілкування 3 іншими користувачами медіа і вміти критично оцінювати власну медіаактивність» (Волошенюк О. В., 2013, c. 348). Останнім часом деякі медіапедагоги висувають нове бачення медіакомпетентності / медіаграмотності, називаючи іiі «інтермедіальною компетенцією» (Онкович Г. В., Горун Ю. М., Кравчук В. О., 2013, c. 8). Водночас із поняттями «інформаційна грамотність» та «медіаграмотність» 3'явилося й поняття «медіа-інформаційна грамотність». Термінологічний рух триває. Проте, незважаючи на неабиякий інтерес, що виявляють науковці до питань неперервної освіти, а саме: професійної підготовки, підвищення кваліфікації, перепідготовки вчителів, залишається малодослідженою проблема розвитку медіакомпетентності педагогів у системі післядипломної освіти як у теоретичному, так і практичному аспектах, що викликано передусім новизною самого явища медіаосвіти, а також невизначеністю науково-методичних засад розвитку в учителів медіаосвітніх компетентностей. Важливо зазначити, що «перелік наведених функціональних обов'язків, якими повинен оволодіти учитель для навчання учнів у інформатизованому освітньому середовищі, дозволяє зробити висновок про доцільність виділення в його 
медіаосвіті світоглядного, методологічного і прикладного блоків» (Шарко В. Д., 2018, c. 42-58) та необхідність одночасного розвитку мотиваційно-ціннісного, технічного, комунікативно-творчого та когнітивного компонентів медіакомпетентності педагогів.

Необхідно зауважити, що питання розвитку медіакомпетентності громадян в Україні починає активно розвиватися з 2008 року за підтримки Міжнародного благодійного фонду «Академія Української Преси» (В. Ф. Іванов., О. В. Волошенюк); Інституту інноваційних технологій і змісту освіти; Інституту соціальної та політичної психології (Л. А. Найдьонова, завідувач лабораторії психології масової комунікації та медіаосвіти). Об'єднавшись, науковці і практики розробили Концепцію впровадження медіаосвіти в Україні (нова редакція), у якій прописано роль ППО у вирішенні проблеми медіаосвіти педагогів (Концепція впровадження медіаосвіти в Україні. [Електронний ресурс]. - Режим доступу: http://www.ispp.org.ua/bibl_2.htm):

- розроблення стандартів медіаінформаційної грамотності педагогів, уведення медіакомпетентності у професійні стандарти підготовки педагогів, психологів, спеціалістів із соціальної роботи та інших спеціальностей, відповідне врахування вимог медіаінформаційної грамотності в освітніх і освітньо-наукових програмах фахової підготовки, розроблення спеціалізованих навчальних медіаосвітніх курсів для перепідготовки фахівців;

- активізація співпраці закладів, які готують фахівців для медіавиробництва і сфери мистецтва, iз Національною академією наук України, Національною академією педагогічних наук України, Національною академією мистецтв України, зокрема для проведення міждисциплінарних досліджень із проблем розвитку медіаосвіти, на- лагодження обміну досвідом і кадрового забезпечення викладання спеціальних дисциплін для медіапедагогів.

У концепції (на III етапі подальшого розвитку медіаосвіти та забезпечення іiі масового впровадження (2021-2025 роки) передбачено внесення в навчальні програми закладів освіти (вищої та післядипломної) iз гуманітарної підготовки фахівців усіх профілів медіаосвітньої складової.

Із 2010 до 2016 року в Україні проведено Всеукраїнський експеримент «Науково-методичні засади впровадження вітчизняної моделі медіаосвіти в навчально-виховний процес загальноосвітніх навчальних закладів» (Постанова Президії Національної академії педагогічних наук України №1-7/10-192 від 23.06.2011 року «Про підготовку всеукраїнського експерименту 3 упровадження медіаосвіти в навчально-виховний процес загальноосвітніх навчальних закладів», Наказ $\mathrm{MOH}$ молоді та спорту України № 886 від 27.07.11 року «Про проведення всеукраїнського експерименту з упровадження медіаосвіти в навчально-виховний процес загальноосвітніх навчальних закладів»). Мета експерименту - розроблення та впровадження державних стандартів, навчальних програм фахової підготовки медіапедагогів і медіапсихологів; організація їх підготовки на базі закладів вищої та післядипломної освіти; запровадження інтегрованої медіаосвіти в початковій та основній школі, факультативних медіаосвітніх курсів тощо.

Нині триває Всеукраїнський експеримент «Стандартизація наскрізної соціально-психологічної моделі масового впровадження медіаосвіти у вітчизняну наукову практику». Експериментальна діяльність зосередилася на етапі подальшого розвитку медіаосвіти та продовження іiі масового впровадження (2017-2020). Науковці та практики працюють над науково-методичним та організаційним забезпеченням процесу активного широкого впровадження медіаосвіти в закладах дошкільної, загальної та професійно-технічної освіти 3 
урахуванням практичних проблем, набутого досвіду, реалізації відповідного психолого-педагогічного супроводу; уведенням у навчальні програми закладів вищої та післядипломної освіти (гуманітарний напрям) медіаосвітньої складової; створенням і поліпшенням матеріально-технічної бази для впровадження медіаосвіти, оснащення медіапедагогів інноваційними інформаційно-комунікаційними технологіями; активізацією співпраці освітян із медіавиробниками для розширення практики медіаосвіти; забезпеченням наукового супроводу медіаосвіти для підвищення іiі ефективності через розроблення прикладних науково-дослідних тем.

\section{Із досвіду роботи обласної творчої групи вчителів зарубіжної літератури закладів загальної середньої освіти Миколаївської області}

\section{«Розвиток медіакомпетентності вчителя літератури»}

Однією з ефективних форм розвитку медіакомпетентності вчителів-предметників є створення медіапедагогами (педагоги, які пройшли навчання чи брали участь у Всеукраїнських експериментах із медіаосвіти) творчих лабораторій.

Відповідно до плану роботи Миколаївського обласного інституту післядипломної педагогічної освіти на 2020 рік, для підвищення фахового рівня вчителів зарубіжної літератури закладів загальної середньої освіти Миколаївської області, розвитку загальнопедагогічної медіакомпетентності вчителя літератури (мотиваційно-ціннісного, технічного, когнітивного та комунікативно-творчого компонентів), реалізації Концепції «Нова українська школа» створена обласна творча група вчителів зарубіжної літератури закладів загальної середньої освіти Миколаївської області «Розвиток медіакомпетентності вчителя літератури» (далі - Творча група). Керівник Творчої групи - О. М. Казакова, заступник директора Миколаївського муніципального колегіуму 3 наукової роботи, учи- тель зарубіжної літератури, учасник Усеукраїнських експериментів із медіаосвіти (2011-2021 рр.). Науковий супровід роботи групи здійснювали В. І. Шуляр, доктор педагогічних наук, доцент, професор кафедри теорії й методики мовно-літературної та художньо-естетичної освіти, директор Миколаївського обласного інституту післядипломної педагогічної освіти; Г. М. Гич, кандидат педагогічних наук, доцент, завідувач кафедри теорії й методики мовно-літературної та художньо-естетичної освіти; організаційно-методичний супровід Г. В. Пономаренко, методист кафедри МОІППО.

\section{Результати роботи Творчої групи}

Творча група працювала в дистанційному (синхронному) режимі протягом трьох сесій та в дистанційному (асинхронному) режимі в міжсесійний період.

Перша сесія відбулася протягом десяти днів (онлайн). Мета: розвиток індивідуальної медіакомпетентності вчителя літератури (технічного, когнітивного та комунікативно-творчого компонентів); робота з поняттями інфодемія, медіагігієна, медіаімунітет.

Платформи для спілкування: постійний чат у мобільному додатку Viber, у якому учасники щодня викладали новий матеріал про нормативно-правову базу медіаосвіти, нові підходи до формування медіакомпетентності вчителів в умовах мобільної реалізації масштабного дистанційного навчання; розглядали важливі питання розвитку індивідуальної складової медіакомпетентності вчителів. У чаті вели обговорення та дискусії; надавали покликання на медіазаходи, що проводили на вітчизняних освітніх платформах.

Платформи для навчання: конференції ZOOM та робота в Google-класі.

Тематика онлайн-зустрічей:

- «Індивідуальний компонент медіакомпетентності вчителя: теоретична складова. Медіакомпетентність як одна зі складових дистанційної освіти». 
- «Протидія медіаманіпуляціям: що вчитель має знати і вміти».

- «Інфодемія як виклик медіапростору».

- «Медіатекст та різновиди його аналізу».

- «Медіаманіпуляції та критичне мислення».

- «Медіатехнології та їхня реалізація в життєвому просторі».

Паралельно проходила робота в Google-класі (розміщували всі Google-презентації, збірники із розробками медіазанять, завдання), що давало можливість учасникам Творчої групи повторити та закріпити здобуті знання.

Рефлексія здійснена до і після проведення курсу: 21 учитель заповнив чотири Google-форми (мотиваційно-ціннісний, технічний, когнітивний та комунікативно-творчий компоненти медіакомпетентності вчителя). Продуктом діяльності групи стала колективно розроблена модель медіазаняття для учнів старшої школи і вчителів та методична збірка «Розвиток індивідуальної медіакомпетентності вчителя».

Передбачена і робота між засіданнями: розроблення індивідуального медіазаняття (тренінгу), формування збірника «Інфодемія та шляхи іiі подолання» (система тренінгових занять).

Друга сесія тривала тиждень. Мета: розвиток загальнопедагогічної медіакомпетентності вчителя літератури (технічного, когнітивного та комунікативно-творчого компонентів).

На заняттях розглядали такі питання: «Основні освітні платформи та застосунки», «Перспективи інтеграції дистанційного навчання в освітній процес із вересня 2020 року (досвід Німеччини»)», «Ефективна взаємодія в освіті: інструменти та прийоми» (програма для тестування та діагностики Plickers, програма для створення QR-кодів, інструмент для креативного планування і контролю роботи класу ClassDojo, онлайн-ресурс, що допоможе педагогам організувати плідну командну роботу учнів Trello, конструктор, який доз- воляє обрати будь-який шаблон для створення інтерактивного контенту Н5Р тощо).

Учасники Творчої групи обмінювалися досвідом із питань: «Можливості медіа в освітньому просторі», «Використання мемів для навчання і виховання», «Проведення інтерактивних вправ (дудлів)», «Ресурси для створення креалізованих текстів: meme arsenal, Risovach, PikselLab, Picsart та інші».

На зустрічах розглядалися питання щодо формування комунікативно-творчого компонента медіакомпетентності вчителя, вирішувалося проблемне питання «Як просувати власний педагогічний бренд: роль сайтів і блогів».

Значна увага під час роботи групи присвячена психолого-педагогічній проблемі медіаризиків, основну увагу приділили трьом питанням: кібербулінг, парасоціальні стосунки та вікові медіаризики. Запропоновані алгоритми вирішення цих надскладних питань.

Учасники Творчої групи дійшли висновку, що оскільки сучасний світ швидко змінюється, i, відповідно, стрімко виникають нові медіавиклики, медіакомпетентний учитель має систематично навчитися сам $\mathrm{i}$ навчити учнів протидіяти їм

На занятті «Медіатехнології та їхня реалізація в освітньому просторі» педагоги представили медіаосвітній прийом «Моя медіабіографія». Учителі розглядали різнобічний вплив медіа (позитивний i негативний) у різних періодах свого життя, на прикладі своїх дітей та героїні роману О. С. Пушкіна Тетяни Ларіної. Це дозволило педагогам з'ясувати, які медіа мають вплив на формування особистості учнів, виявити ризики, що викликає медіа, окреслити надані медіаможливості.

Групою розглянуто використання технології фактчекінгу на уроках та медіазаняттях. Спікери окреслили шляхи перетину онлайн-траєкторій учителя та учнів, продемонструвавши свою сторінку в мережі Instagram. Педагоги показали різноманітні медіаприйоми роботи з батьками, запропонували настанови (на кшталт на- 
вчання дітей корисним онлайн-траєкторіям).

Значну увагу під час роботи Творчої групи приділено висвітленню питання медіаосвіти в контексті роботи МАН, педагоги представили учнівські роботи, які стали переможцями та призерами Всеукраїнського етапу конкурсу-захисту науково-дослідних робіт МАН.

Учасники отримали завдання: розробити конспект уроку зарубіжної літератури з елементами формування медіакомпетентності учнів, створити власний інтерактивний блог або сайт.

Під час третьої сесії в дистанційному (синхронному) режимі на платформі «Zoom» відбулося три засідання.

На першому засіданні висвітлено питання «Імерсивна педагогіка в контексті уроків зарубіжної літератури» із наукового, методичного, практичного погляду.

Під час другої онлайн-зустрічі розглянуті питання: робота у програмі «Канва» під час вивчення творчості В. Шекспіpa, динамічний сторітейлінг, використання хмарних технологій під час проведення контрольних робіт та творчих завдань, використання соціальних мереж під час виконання групової роботи. Підсумком роботи між засіданнями стала презентація матеріалів збірки «Палітра уроків зарубіжної літератури на мольберті сучасності: розвиток медіакомпетентності учнів». Власні розробки представили вчителі зарубіжної літератури 33СО Миколаївської області: Тамара Дротенко, Вікторія Заболотня, Олена Колива, Світлана Криворученко, Людмила Ковальська, Тетяна Вечерковська, Тетяна Кривенька.

На третьому засіданні «Урок літератури як гіпертекст» Василь Шуляр, доктор педагогічних наук, професор кафедри, директор Миколаївського обласного інституту післядипломної педагогічної освіти, заслужений учитель України, автор статей, що присвячені гіпертекстовому підходу на уроках літератури, зосередив увагу учасників засідання на основних теоретико-філософських поняттях медіаосвіти суб'єктів педагогічного процесу. Практичну частину питання «Урок як гіпертекст» на прикладі вивчення теми «Вергілій. «Енеїда» представила Оксана Казакова.

Варто зазначити, що порівняння результатів вхідного і вихідного тестування продемонструвало позитивну динаміку розвитку предметної медіакомпетентності вчителя літератури (мотиваційно-ціннісного, технічного, когнітивного та комунікативно-творчого компонентів), що свідчить про ефективність роботи Творчої групи.

Продуктом роботи $\epsilon$ науково-методичний посібник «Розвиток медіакомпетентності учнів на уроках зарубіжної літератури та позакласних заходах», що допоможе формувати та розвивати медіакомпетентність учнів саме на уроках зарубіжної літератури та в позакласній роботі 3 предмета.

Отже, реалізація вітчизняної Концепції впровадження медіаосвіти в умовах інститутів післядипломної педагогічної освіти здійснюється через створення творчих груп на кшталт обласної творчої групи вчителів зарубіжної літератури закладів загальної середньої освіти Миколаївської області «Розвиток медіакомпетентності вчителя літератури». Розвиток медіакомпетентності вчителів розглянуто в зарубіжній і вітчизняній науковій літературі та нормативних документах; у розглянутій статті Концепції зазначено, що медіаосвіта педагогів носить масовий характер і велику роль у цьому відіграють ОІППО. Проте є суперечності між вимогами сьогодення та рівнем медіакомпетентності педагогів, кількістю досвідчених медіапедагогів. Звертають на себе увагу функції сучасного вчителя як провідника у світі медіа: забезпечення ефективного використання учнями медіапростору, профілактика та запобігання медіаризиків, розвиток соціально-комунікативного, технічного та когнітивного компонентів медіакомпетентності учнів.

Нині завдяки спільним зусиллям науковців, методистів, учителів-практиків на базі Миколаївського обласного інституту післядипломної педагогічної освіти роз- 
роблено програму розвитку медіакомпетентності вчителів зарубіжної літератури та запропоновано педагогам індивідуальні освітні траєкторії (зокрема й онлайн-траєкторії) розвитку загальнопрофесійної і предметної медіакомпетентності. Ми вважаємо, що ефективним шляхом розвитку всіх компонентів медіакомпетентності вчителів-предметників $є$ створення творчих груп, робота яких спрямовуватиметься на формування індивідуальної, загальнопедагогічної та предметної медіакомпетентно- сті вчителя.

Перспективи подальших дослі-
джень.
Актуальним є постійний пошук нових форм і методів розвитку медіакомпетентності вчителів, адже медіасвіт є доволі динамічним і педагогу необхідно постійно набувати нові компетентності для ефективної взаємодії з ним. Важливим для подальших педагогічних досліджень є питання впровадження імерсивних технологій у сучасний освітній простір.

\title{
ЛІТЕРАТУРА
}

1. Єрмоленко А. О. Медіакомпетентність як необхідна складова професійної майстерності сучасного педагога / А. О. Срмоленко // Вісник Чернігівського національного педагогічного університету. Серія : Педагогічні науки. - 2016. - Вип. 137. - С. 330-333. - Режим доступу: http://nbuv.gov.ua/UJRN/VchdpuP_2016_137_80

2. Іванов В. Ф. Медіакомпетентність як необхідна складова професійної майстерності сучасного педагога / В. Ф. Іванов, Т. В. Іванова // Інформаційне суспільство. - 2014. - Вип. 20. - С. 96-99. - Режим доступу: http://nbuv.gov.ua/UJRN/is_2014_20_23

3. Концепція впровадження медіа-освіти в Україні. [Електронний ресурс]. - Режим доступу: http://www.ispp.org.ua/bibl_2.htm

4. Медіакомпетентність фахівця : колектив. монографія / Онкович Г. В., Горун Ю. М., Кравчук В. О. [та ін.] ; за наук. ред. Г. В. Онкович ; Нац. акад. пед. наук України, Ін-т вищ. освіти НАПН України. - Київ : Логос, 2013. - 287 с.

5. Медіаосвіта та медіаграмотність: підруч. для студ. вищ. пед. навч. закл. та слухачів Ін-тів підвищ. кваліфікації вчителів / [авт. кол. : О. В. Волошенюк ; ред.-упоряд. : В. Ф. Іванов, О. В. Волошенюк]. - Вид. 2-ге, стер. - Київ : Академія Української Преси : Центр Вільної Преси, 2013. - 352 с. - Бібліогр. : С. 341-342.

6. Найдьонова Л. А. Медіапсихологія: основи рефлексивного підходу : підруч. для слухачів системи післядиплом. пед. освіти / Любов Антонівна Найдьонова ; [літ. редагування Медюка Ю. Г.] ; Нац. акад. пед. наук України, Ін-т соц. та політ. психології Нац. акад. пед. наук України. - Вид. 2-ге, стер. - Кіровоград : Імекс ЛТД, 2015. - 243 с.

7. Шарко В. Д. Медіакомпетентність як складова методичної підготовки вчителя та iї діагностування [Електронний ресурс] / В. Д. Шарко. - Херсон, 2018. - С. 42-58. - Режим доступу: http://ekhsuir.kspu.edu/handle/123456789/1014

8. Nazarenko L., Palamar S. European development trends and regional aspect. - 1st ed. - Riga, Latvia : Baltija Publishing, 2020 - 273-294 pp. Doi: https://doi.org/10.30525/9789934-588-38-9-13--

\section{РАЗВИТИЕ МЕДИАКОМПЕТЕНТНОСТИ УЧИТЕЛЯ ЛИТЕРАТУРЫ В КОНТЕКСТЕ ДЕЯТЕЛЬНОСТИ ИНСТИТУТОВ ПОСЛЕДИПЛОМНОГО ПЕДАГОГИЧЕСКОГО ОБРАЗОВАНИЯ}

\author{
Казакова Оксана, \\ заместитель директора по научной работе \\ Николаевский муниципальный коллегиум им. В. Д. Чайки \\ ул. Котельная, 8, 54000, г. Николаев, Украина \\ oksiniki@ukr.net
}




\begin{abstract}
Пономаренко Анна,
методист кафедры теории и методики языково-литературного и художественно-эстетического образования Николаевский областной институт последипломного педагогического образования ул. Адмиральская, 4-а, 54001, г. Николаев, Украина anna.ponomarenko@moippo.mk.ua
\end{abstract}

Статья посвящена одному из актуальных вопросов современной отечественной педагогической науки - медиакомпетентности учителя. В частности раскрывается сущность таких понятий, как медиаобразование, медиаграмотность, медиаосведомлённость, медиакомпетентность. Внимание сосредотачивается на выяснении степени разработки исследуемой проблемы в научном и нормативно-правовом поле Украины: рассмотрена Концепџия «Новой украинской школьл», Конщепџия внедрения медиаобразования в Украине.

Определень подходы к внедрению медиаобразования в украинское образовательное пространство, его иели, задачи. Названы основные функиии педагога, необходимые для формирования медиакомпетентности учащихся. Указаны противоречия, мешаюшие эффективно реализовывать программу новой украинской школь по имплементации медиаобразования в школьную среду (такие, как разногласия между современными требованиями общества к профессиональной деятельности учителя, которая долюна обеспечить создание медиаобразовательной средь, и неготовностью большинства педагогов кее осуществлению).

В статье поднимаются вопросы медиаинформационной грамотности, медиаиммунитета личности, рефлексии и критического мылиения (как психологических механизмов, обеспечивающих сознательное потребление медиапродукции и саморегуляцию взаимодействия с медиа), способности к медиатворчеству и специализированным аспектам медиакультуры.

Ключевые слова: кибербулинг; медиаграмотность; медиазависимость; медиакомпетентность; медиакомпетенщия; медиакультура; медиаобразование; медиаосведомлённость.

\title{
MEDIA COMPETENCE DEVELOPMENT OF A LITERATURE TEACHER IN THE CONTEXT OF THE POSTGRADUATE EDUCATION
}

\author{
Kazakova Oksana, \\ Deputy Director, \\ Mykolaiv Municipal Collegium named after Volodymyr Chaika \\ 8 Kotelna Street, 54000, Mykolaiv, Ukraine \\ oksiniki@ukr.net
}

Ponomarenko Hanna, educator, Department of Theory and Methods of Language, Literature, Art and Aesthetic Education Mykolaiv In-Service Teachers Training Institute 4-a Admiralska Street, 54001, Mykolaiv, Ukraine anna.ponomarenko@moippo.mk.ua

The article is devoted to the issue of teacher's media competence. In particular, the essence of such concepts as media education, media literacy, media awareness, media competence is revealed. Attention is focused on some aspects of this issue in the scientific and legal field of 
Ukraine, including the Concept of the New Ukrainian school, the Concept of media education in Ukraine.

Approaches to the media education in Ukraine, its purpose, tasks are determined. The main teacher's functions that are necessary to develop students' media competence are indicated. There are contradictions that hinder the implementation of media education in the New Ukrainian School's learning space (such as inconsistencies between modern society's requirements for teachers' activities and the unwillingness of teachers to implement it).

The article considers issues of media information literacy, media immunity, ability to reflect and think critically as psychological mechanisms that ensure conscious consumption of media products and self-regulation.

The work of the creative group of Literature teachers from Mykolayiv region is presented. The content devoted to media competence development and forms of distance work of this teachers' group are introduced. There are three aspects: individual (a personal indicator of readiness to develop media education of schoolchildren), general professional which is connected with digital literacy of the media world which, and the subject's one which related to the specifics of Foreign Literature. The results of input and output diagnostics are given, which demonstrates the effectiveness of mentioned approaches to the teacher's media competence development.

Keywords: cyberbullying; media awareness; media competence; media culture; media dependence; media education; media literacy.

\section{REFERENCES}

1. Ivanov, V. F. \& Ivanova, T. V. (2014). Mediakompetentnist yak neobkhidna skladova profesiinoi maisternosti suchasnoho pedahoha [Media competence as a necessary component of professional skills of a modern teacher]. Informatsiine suspilstvo, 20, 96-99. Retrieved from: http://nbuv.gov.ua/UJRN/is_2014_20_23 (ukr).

2. Kontseptsiia vprovadzhennia media-osvity v Ukraini (2016). [The concept of introducing media education in Ukraine.]. Retrieved from: http://www.ispp.org.ua/bibl_2.htm (ukr).

3. Naidonova, L. A. \& Mediuk, Yu. H. (Ed.) (2015). Mediapsykholohiia: osnovy refleksyvnoho pidkhodu [Media psychology: the basics of a reflexive approach]. Nats. akad. ped. nauk Ukrainy, In-t sots. ta polit. psykholohii Nats. akad. ped. nauk Ukrainy. Vyd. 2, ster. Kirovohrad: Imeks LTD (ukr).

4. Nazarenko L., Palamar S. European development trends and regional aspect. - 1st ed. - Riga, Latvia : Baltija Publishing, 2020. - 273-294 pp. Doi: https://doi.org/10.30525/9789934-588-38-9-13--(ukr).

5. Onkovych, H. V., Horun, Yu. M., Kravchuk, V. O. et al. (2013). Mediakompetentnist fakhivtsia [Media competence of the specialist]. Nats. akad. ped. nauk Ukrainy, In-t vyshch. osvity NAPN Ukrainy. Kyiv : Lohos (ukr).

6. Sharko, V. D. (2018). Mediakompetentnist yak skladova metodychnoi pidhotovky vchytelia ta yii diahnostuvannia [Media competence as a component of methodical training of teachers and its diagnosis]. Kherson, 42-58. Retrieved from: http://ekhsuir.kspu.edu/ handle/123456789/ (ukr).

7. Volosheniuk, O. V. \& Ivanov, V. F. (ed.-order.) (2013). Mediaosvita ta mediahramotnist [Media education and media literacy]. Vyd. 2-he, ster. Kyiv: Akademiia Ukrainskoi Presy: Tsentr Vilnoi Presy (ukr).

8. Yermolenko, A. O. (2016). Mediakompetentnist yak neobkhidna skladova profesiinoi maisternosti suchasnoho pedahoha [Media competence as a necessary component of professional skills of a modern teacher]. Visnyk Chernihivskoho natsionalnoho pedahohichnoho universytetu. Seriia: Pedahohichni nauky, 137, 330-333. Retrieved from: http://nbuv.gov.ua/ UJRN/VchdpuP_2016_137_80 (ukr). 